\title{
IMPLEMENTASI KONSEP PELAKSANAAN KEBIJAKAN DALAM PUBLIK
}

\author{
Jumria Mansur \\ Jurusan Syariah Prodi Muamalah, Institut Agama Islam Negeri Pare-Pare \\ Email: Jumriamr@gmail.com
}

\begin{abstract}
The purpose of writing this article is to discuss general concepts about implementing public policy. The preparation of this article is carried out with the main reference sources from various literatures and research relevant to the implementation of public policy, which is complemented by the author's thoughts on the topic presented. The results of the discussion indicate that the implementation of public policy is influenced by several factors, including: aspects of authority, resources, communication, and disposition. Meanwhile, the evaluation of policy implementation needs to be carried out comprehensively, which includes: ex-ante, on- going, and ex-post evaluations of the implementation of public policies. In carrying out innovations and breakthroughs in service to the public, discretion can be carried out in the implementation of public policies as long as they do not conflict with applicable norms and regulations.
\end{abstract}

Keywords: Public policy implementation; public policy

\begin{abstract}
Abstrak
Tujuan penulisan artikel ini adalah untuk membahas konsep umum tentang pelaksanaan kebijakan publik. Metode penelitian menggunakan pendekatan kualitatif. Penyusunan artikel ini yang dilakukan dengan pelaksanaan kebijakan publik, yang dilengkapi dengan pemikiran penulis atas topik yang disajikan. Hasil pembahasan menunjukkan bahwa implementasi kebijakan publik dipengaruhi oleh beberapa faktor, diantaranya: aspek kewenangan, sumberdaya, komunikasi, dan disposisi. Dimensidimensi yang dapat digunakan untuk mengevaluasi pelaksanaan kebijakan publik diantaranya: konsistensi, transparansi, akuntabilitas, keadilan, efektivitas, dan efisiensi. Sementara itu evaluasi pelaksanaan kebijakan perlu dilakukan secara komperhensif, yang meliputi: evaluasi ex-ante, on-going, dan ex-post atas pelaksanaan kebijakan publik. Dalam melakukan inovasi dan terobosan dalam pelayanan kepada publik, dapat dilakukan diskresi pelaksanaan kebijakan publik sepanjang tidak bertentangan dengan norma dan peraturan yang berlaku.
\end{abstract}

Kata kunci: Implementasi kebijakan publik; kebijakan publik

\section{Pendahuluan}

Implementasi kebijakan merupakan hal yang sangat luas, meliputi bagaimana implementasi ditempatkan sebagai alat administasi hukum dan juga sekaligus dipandang sebagai fenomena kompleks sebuah proses atau hasil dari kebijakan. Situmorang juga menegaskan bahwa implementasi kebijakan adalah satu dari sekian banyak tahap kebijakan publik, sekaligus menjadi variabel terpenting yang memiliki pengaruh sangat besar terhadap keberhasilan kebijakan terkait penyelesaian isu-isu publik (Situmorang Chazali, 2016).

Terbitnya kebijakan publik dilandasi kebutuhan untuk penyelesaian masalah yang terjadi di masyarakat. Kebijakan publik ditetapkan oleh para pihak (stakeholders), terutama pemerintah yang diorientasikan pada pemenuhan kebutuhan dan kepentingan masyarakat. Makna dari pelaksanaan kebijakan publik merupakan suatu hubungan yang memungkinkan pencapaian tujuan-tujuan atau sasaran sebagai hasil akhir dari kegiatan yang dilakukan pemerintah. Kekurangan atau kesalahan 
kebijakan publik akan dapat diketahui setelah kebijakan publik tersebut dilaksanakan, keberhasilan pelaksanaan kebijakan publik dapat dilihat dari dampak yang ditimbulkan sebagai hasil evaluasi atas pelaksanaan suatu kebijakan (Andayaningsih Hernaman, 2018).

Pelaksanaan kebijakan secara sederhana adalah pelaksanaan atau penerapan suatu kebijakan. Pelaksanaan kebijakan bermuara pada aktifitas, aksi, tindakan, atau mekanisme yang dibingkai pada suatu sistem tertentu. Pelaksanaan kebijakan merupakan suatu kegiatan terencana yang dilkukan secara sungguh-sungguh berdasarkan acuan norma tertentu yang diarahkan untuk mencapai tujuan tertentu (Warjio Afandi.2015)

Pelaksanaan kebijakan tidak hanya menyangkut perilaku lembaga administratif yang bertanggung jawab untuk melaksanakan program, melainkan menyangkut pula pada partisipasi masyarakat, kekuatan politik, ekonomi dan sosial dengan berbagai pihak. Pelaksanaan kebijakan yang dilaksanakan secara tepat sasaran dan berdaya guna akan mampu memecahkan suatu permasalahan secara baik, semakin kompleks permasalahan kebijakan dan semakin mendalam analisis yang digunakan, semakin diperlukan teori dan modal yang mampu menjelaskan ketepatan pelaksanaan kebijalan tersebut (Andayaningsih Hernaman, 2018). Analisa kebijakan perlu dilakukan, tertutama berkenaan dengan dampak yang dihasilkannya. Kajian pelaksanaan kebijakan bertujuan agar suatu kebijakan tidak bertentangan dan merugikan kepentingan masyarakat.

Artikel ini bertujuan untuk membahas konsep dasar pelaksanaan kebijakan publik, untuk kemudian dapat dijadikan acuan dalam melakukan evaluasi dan analisa atas pelaksanaan kebijakan publik. Unuk mencapai tujuan tersebut penulis membaca beberapa literatur yang dapat dijadikan bahan referensi dalam penulisan artikel ini.

\section{Kajian Pustaka}

\section{Implementasi Kebijakan Publik Implementasi Kebijakan}

Implementasi kebijakan itu pada prinsipnya adalah cara atau langkah yang dilakukan agar sebuah kebijakan dapat mencapai tujuannya, oleh Mazmanian dan Sabatier (1983) dalam (Warjio Afandi 2015) disebut sebagai upaya melaksanakan keputusan. Peter deLeon dan Linda deLeon (2001) menyatakan bahwa pendekatan- pendekatan dalam implementasi kebijakan publik dapat dikelompok menjadi tiga generasi. yaitu: (1) pada tahun 1970-an, memahami implementasi kebijakan sebagai masalahmasalah yang terjadi antara kebijakan dan eksekusinya. Pada generasi ini, implementasi kebijakan berimpitan dengan studi pengambilan keputusan di sektor publik. (2) pada tahun 1980-an, adalah generasi yang mengembangkan pendekatan implementasi kebijakan yang bersifat "dari atas ke bawah". Perspektif ini lebih fokus pada tugas birokrasi untuk melaksanakan kebijakan yang telah diputuskan secara politik, (3) pada tahun 1990- 
an memperkenalkan pemikiran bahwa variabel perilaku dari aktor pelaksana implementasi kebijakan yang lebih menentukan keberhasilan implementasi kebijakan.

Pendekatan kontijensi atau situasional dalam implementasi kebijakan yang mengemukakan bahwa implementasi kebijakan banyak didukung oleh adaptabilitas implementasi kebijakan tersebut. Mengimplementasikan suatu kebijakan publik dapat dilakukan dua pilihan, yaitu langsung mengimplementasikan dalam bentuk programprogram dan diimplementasikan melalui formulasi kebijakan derivat atau turunan dari suatu kebijakan publik (Younistalb. Ed, 2015).

\section{Model-Model Implementasi Kebijakan Publik}

Model-model implementasi kebijakan publik menurut Gortner Harold, 2001 dalam (Yamin M. N, 2016), antara lain :

a. Model Van Meter dan Van Horn

Model ini mengandaikan bahwa implementasi kebijakan berjalan secara linear dari kebijakan publik, implementor, dan kinerja kebijakan publik. Beberapa variabel yang dimasukkan sebagai variabel yang mempengaruhi kebijakan publik, implementor, dan kinerja kebijakan publik. Beberapa variabel yang dimasukkan sebagai variabel yang mempengaruhi kebijakan publik adalah variabel: aktivitas implementasi dan komunikasi antarorganisasi, karakteristik agen pelaksana/implementor, kondisi ekonomi-sosial-politik, dan kecenderungan (disposition) pelaksana/implementor.

b. Model Mazmanian dan Sabatier

Model ini disebut model kerangka analisis implementasi (a framework for implementation analysis). Model ini mengklasifikasikan proses implementasi kebijakan ke dalam tiga variabel. Variabel tersebut adalah variabel independen, variabel intervening, dan variabel dependen.

c. Model Hogwood dan Gunn

Model ini mendasarkan pada konsep manajemen strategis yang mengarah pada praktik manajemen yang sistematis dan tidak meninggalkan kaidah-kaidah pokok. Kelemahannya, konsep ini secara tidak tegas menunjukkan nama yang bersifat politis, strategis, dan teknis atau operasional.

d. Model Goggin, Bowman, dan Lester

Model ini bertujuan mengembangkan model implementasi kebijakan yang "lebih ilmiah" dengen mengedapankan pendekatan "metode penelitian" dengan adanya variabel independen, intervening, dan dependen, dan meletakkan faktor "komunikasi" sebagai penggerak dalam implementasi kebijakan.

e. Model Grindle

Model ini ditentukan oleh isi kebijakan dan konteks implementasinya. Ide dasarnya adalah bahwa kebijakan ditransformasikan, maka implementasi kebijakan dilakukan. Keberhasilannya ditentukan oleh derajat implementability dari kebijakan tersebut.

f. Model Elmore, dkk

Model implementasi ini didasarkan pada jenis kebijakan publik yang mendorong masyarakat untuk mengerjakan sendiri implementasi kebijakan atau tetap melibatkan pejabat pemerintah namun hanya di tataran rendah.

g. Model George C. Edward III

Model ini menegaskan bahwa masalah utama Administrasi Publik adalah lack of attention to implementation (kurangnya perhatian dari implementasi). Dikatakannya, without effective 
implementation the decision of policymakers will not be carried out successfully (tanpa implementasi yang efektif, pembuat kebijakan tidak akan berjalan lancar). Edward menyarankan untuk memerhatikan empat isu pokok agar implementasi kebijakan menjadi efektif yaitu : komunikasi, resources, disposition, dan struktur birokrasi.

h. Model Nakamura dan Smallwood

Model ini menautkan pembentukan kebijakan dalam implementasi kebijakan secara praktikal. Konsep ini menjadi magnet yang sangat besar terhadap para praktisi kebijakan, yang justru mendekatkan ilmuwan kebijakan dan praktisi kebijakan. Kedekatan ini menjadikan pengetahuan implementasi kebijakan semakin mampu mengkontribusikan nilai bagi kehidupan bersama. Konsekuensinya adalah pengetahuan implementasi kebijakan tidak lagi menjadi monopoli para professor kebijakan publik, namun juga para praktisnya di birokrasi dan lembaga Administrasi Publik lainnya.

i. Model Jaringan

Model ini memahami bahwa proses implementasi kebijakan adalah sebuah complex of interaction processes di antara sejumlah aktor besar yang berada dalam suatu jaringan (network) aktor-aktor yang independen, interaksi di antara para aktor dalam jaringan tersebutlah yang akan menentukan bagaimana implementasi harus dilaksanakan, permasalahan- permasalahan yang harus dikedepankan, dan diskresi-diskresi yang diharapkan menjadi bagian penting di dalamnya.

\section{Pelaksanaan Kebijakan Publik \\ Kebijakan Publik}

Kebijakan dapat didefinisikan sebagai serangkaian rencana program, aktivitas, aksi, keputusan, sikap, untuk bertindak maupun tidak bertindak yang dilakukan oleh para pihak (aktor-aktor), sebagai tahapan untuk penyelesaian masalah yang dihadapi. Penetapan kebijakan merupakan suatu faktor penting bagi organisasi untuk mencapai tujuannya (Iskandar, 2017).

Menurut (Egetan. M, 2015) kebijakan memiliki dua aspek, yakni:

a. Kebijakan merupakan praktika sosial,

kebijakan bukan event yang tunggal atau terisolir. Dengan demikian, kebijakan merupakan sesuatu yang dihasilkan pemerintah yang dirumuskan berdasarkan dari segala kejadian yang terjadi di masyarakat. Kejadian tersebut ini tumbuh dalam praktika kehidupan kemasyarakatan, dan bukan merupakan peristiwa yang berdiri sendiri, terisolasi, dan asing bagi masyarakat.

b. Kebijakan adalah suatu respon atas peristiwa yang terjadi, baik untuk menciptakan harmoni dari pihak-pihak yang berkonflik, maupun menciptakan insentif atas tindakan bersama bagi para pihak yang mendapatkan perlakuan yang tidak rasional atas usaha bersama tersebut. Dengan demikian, kebijakan dapat dinyatakan sebagai usaha untuk mencapai tujuan-tujuan tertentu, sekaligus sebagai upaya pemecahan masalah dengan menggunakan sarana-sarana tertentu, dan dalam tahapan waktu tertentu. Kebijakan umumnya bersifat mendasar, karena kebijakan hanya menggariskan pedoman umum sebagai landasan bertindak dalam usah mencapai tujuan yang telah ditetapkan. Kebijakan bisa berasal dari seorang pelaku atau sekelompok pelaku yang memuat serangkaian program/ aktivitas/ tindakan dengan tujuan tertentu. Kebijakan ini diikuti dan dilaksanakan oleh para pelaku (stakeholders) dalam rangka memecahkan suatu permasalahan tertentu (Andayaningsih Hernaman, 2018). 
Proses kebijakan dapat dijelaskan sebagai suatu sistem, yang meliputi: input, proses, dan output. Input kebijakan merupakan isu kebijakan atau agenda pemerintah, sedangkan proses kebijakan berwujud perumusan formulasi kebijakan dan pelaksanaan kebijakan. Isu dan formulasi kebijakan dapat dipahami sebagai proses politik yang dilakukan elit politik dan/ atau kelompok- kelompok penekan. Output dari proses kebijakan adalah kinerja kebijakan (Wahyudi, 2016). Oleh karena itu, kebijakan tidak bersifat permanen. Kebijakan dibuat sekali untuk rentang waktu tertentu sebagai sebuah solusi atas permasalahan yang ada dan kepentingannya melayani (Godin, Rein, \& Moran, 2006).

Kebijakan publik merupakan suatu ilmu terapan (Erwan Agus Puwanto, 2018). Pengertian kebijakan publik oleh para pakar didefinisikan secara beragam, hal tersebut dipengaruhi oleh berbagai kepentingan yang melandasi perumusannya. (Zainal Abidin,

2017) memberikan penafisiran tentang kebijakan publik sebagai hasil rumusan dari suatu pemerintahan. Dalam pandangan ini, kebijakan publik lebih dipahami sebagai apa yang dikerjakan oleh pemerintah dibandingkan daripada proses hasil yang dibuat.

Mengenai kebijakan publik, lebih lanjut Samodra.W.Dk, 2017 menyatakan bahwa:

a. Kebijakan publik lebih merupakan tindakan sadar yang berorientasi pada pencapaian tujuan daripada sebagai perilaku/ tindakan yangdilakukan secara acak dan kebetulan;

b. Kebijakan publik pada hakekatnya terdiri dari tindakan-tindakan yang saling berkaitan dan memiliki pola tertentu yang mengarah pada pencapaian tujuan tertentu yang dilakukan oleh pemerintah, dan bukan merupakan keputusan yang berdiri sendiri;

c. Kebijakan publik berkenaan dengan aktivitas/ tindakan yang sengaja dilakukan secara sadar dan terukur oleh pemerintah dalam bidang tertentu;

d. Kebijakan publik dimungkinkan bersifat positif dalam arti merupakan pedoman tindakan pemerintah yang harus dilakukan dalam menghadapi suatu masalah tertentu, atau bersifat negatif dalam arti merupakan keputusan pejabat pemerintah untuk tidak melakukan sesuatu.

Berdasarkan pendapat tersebut, kebijakan publik dapat didefinsikan sebagai serangkaian kegiatan yang sadar, terarah, dan terukur yang dilakukan oleh pemerintah yang melibatkan para pihak yang berkepentingan dalam bidang- bidang tertentu yang mengarah pada tujuan tertentu. Sehingga untuk efektivitas kebijakan publik diperlukan kegiatan sosialisasi, pelaksanaan dan pengawasan kebijakan (Samodra.W.Dk, 2017)

Peraturan perundang-undangan sebagai produk dari kebijakan publik merupakan komoditas politik yang menyangkut kepentingan publik. Namun demikian, berbagai dinamika yang terjadi dapat membawa konsekuensi bahwa kebijakan publik pun dapat mengalami perbaikan. Oleh karenanya, kebijakan publik pada satu pandangan tertentu, dipersyaratkan bersifat fleksibel, harus bisa diperbaiki, dan disesuaikan dengan perkembangan dinamika pembangunan. Kesesuaian suatu kebijakan publik sangat tergantung kepada penilaian masyarakat (Rian. N.D, 2017). 
Pembahasan kebijakan publik tidak bisa lepas dari usaha untuk melaksanakan kebijakan publik tersebut. Pelaksanaan kebijakan publik merupakan rangkaian kegiatan setelah suatu kebijakan dirumuskan dan ditetapkan. Pelaksanaan kebijakan mengacu pada mekanisme, sumberdaya, dan hubungan terkait dengan pelaksanaan program. Tanpa pelaksanaannya, kebijakan yang telah ditetapkan akan sia-sia. Oleh karena itu, pelaksanaan kebijakan mempunyai kedudukan yang esensial dalam kebijakan publik kebijakan (Mthethwa. R.M, 2018).

Berkenaan dengan pelaksanaan kebijakan, I.s. Islamy, I, (2019) mengemukakan pengertian kebijakan publik, sebagai berikut:

a. Kebijakan negara dalam bentuk awalnya berupa ketetapan tindakan-tindakan pemerintah.

b. Kebijakan negara itu tidak cukup hanya dinyatakan, tetapi harus dilaksanakan dalam bentuk yang nyata.

c. Kebijakan negara yang baik untuk melakukan sesuatu atau tidak melakukan sesuatu dilandasi dengan maksud dan tujuan tertentu.

d. Kebijakan negara harus senantiasa ditujukan bagi pemenuhan kepentingan seluruh anggota masyarakat.

Pelaksanaan kebijakan merupakan kegiatan lanjutan dari proses perumusan dan penetapan kebijakan. Sehingga pelaksanaan kebijakan dapat dimaknai sebagai tindakan- tindakan yang dilakukan, baik oleh individu maupun kelompok pemerintah, yang diorientasikan pada pencapaian tujuan-tujuan yang telah digariskan dalam keputusan kebijakan. Implikasi dari pelaksanaan kebijakan merupakan konsekuensi yang muncul sebagai akibat dari dilaksanakannya kebijakankebijakan tersebut. Hasil evaluasi pada pelaksanaan kebijakan dapatmenghasilkan dampak yang diharapkan (intended) atau dampak yang tidak diharapkan (spillover negative effect) (I.s. Islamy. I, 2019).

\section{Aspek-aspek yang Mempengaruhi Pelaksanaan Kebijakan Publik}

Menurut Edwards III dalam (Arifin.T, 2018), pelaksanaan kebijakan dapat diartikan sebagai bagian dari tahapan proses kebijaksanaan, yang posisinya berada diantara tahapan penyusunan kebijaksanaan dan konsekuensi-konsekuensi yang ditimbulkan oleh kebijaksanaan tersebut (output, outcome). Lebih lanjut, Edward III mengidentifikasikan aspek-aspek yang diduga kuat berkontribusi pada pelaksanaan kebijakan, yaitu: komunikasi, sumberdaya, disposisi atau sikap pelaksana, dan struktur birokrasi. Keempat aspek mempengaruhi pelaksanaan kebijakan, baik secara langsung maupun tidak secara langsung, dan masing-masing aspek saling berpengaruh terhadap aspek lainnya

\section{a. Komunikasi}

Komunikasi adalah aktivitas yang mengakibatkan orang lain menginterprestasikan suatu ide/ gagasan, terutama yang dimaksudkan oleh pembicara atau penulis melalui sesuatu sistem yang biasa (lazim) baik dengan simbol-simbol, signal- signal, maupun perilaku. Komunikasi mempengaruhi pelaksanaan kebijakan publik, dimana komunikasi yang tidak baik dapat menimbulkan dampak-dampak buruk bagi pelaksanaan kebijakan. Dimensi komunikasi yang dapat mempengaruhi pelaksanaan kebijakan publik diantaranya: transmisi, konsistensi, dan kejelasan. Pencapaian keberhasilan pelaksanaan kebijakan publik mensyaratkan pelaksana untuk mengetahui yang harus dilakukan secara jelas; tujuan dan sasaran kebijakan harus diinformasikan kepada kelompok sasaran (target group) sehingga dapat mengurangi kesenjangan antara rencana dan pelaksanaan kebijakan. Apabila penyampaian informasi tentang tujuan dan sasaran suatu kebijakan 
kepada kelompok sasaran tidak jelas, dimungkinkan terjadi resistensi dari kelompok sasaran (Warjio Afandi, 2015).

Kemampuan komunikasi diarahkan agar pelaksana kegiatan dapat berunding satu sama lain dan menemukan titik kesepahaman/ konsensus yang saling menguntungkan. Konsensus yang terbagun dapat meningkatkan kinerja personal dalam bekerja dengan menemukan kondisi win-win solution pada setiap permasalahan (Christiyanto.S, 2016)

\section{b. Kewenangan/ Struktur Birokrasi}

Kewenangan merupakan otoritas/ legitimasi bagi para pelaksana dalam melaksanakan kebijakan yang ditetapkan secara politik. Kewenangan ini berkaitan dengan struktur birokrasi yang melekat pada posisi/ strata kelembagaan atau individu sebagai pelaksana kebijakan. Karakteristik utama dari birokrasi umumnya tertuang dalam prosedur kerja atau Standard Operating Procedures (SOP) dan fragmentasi organisasi (Warjio Afandi, 2015).

\section{c. Sumberdaya}

Pelaksanaan kebijakan harus ditunjang oleh ketersediaan sumberdaya (manusia, materi, dan metoda). Pelaksanaan kebijakan publik perlu dilakukan secara cermat, jelas, dan konsisten, tetapi jika para pelaksana kekurangan sumberdaya yang diperlukan, maka pelaksanaaan kebijakan akan cenderung tidak dapat dilaksanakan secara efektif. Tanpa dukungan sumberdaya, kebijakan hanya akan menjadi dokumen yang tidak diwujudkan untuk memberikan pemecahan masalah yang ada di masyarakat, atau upaya memberikan pelayanan pada masyarakat. Dengan demikian, sumberdaya merupakan faktor penting dalam melaksanakan kebijakan publik. Sumberdaya dalam pelaksanaan kebijakan publik diantaranya: staf yang memadai, informasi, pendanaan, wewenang, dan fasilitas pendukung lainnya (Warjio Afandi, 2015).

\section{d. Disposisi atau sikap dari pelaksana}

Disposisi adalah watak dan karakteristik yang dimiliki oleh pelaksana kebijakan, seperti komitmen, disiplin, kejujuran, kecerdasan, dan sifat demokratis (Wahab, 2010) dalam (Warjio Afandi, 2015). Apabila pelaksana kebijakan memiliki disposisi yang baik, maka dia diduga kuat akan menjalankan kebijakan dengan baik, sebaliknya apabila pelaksana kebijakan memiliki sikap atau cara pandang yang berbeda dengan maksud dan arah dari kebijakan, maka dimungkinkan proses pelaksanaan kebijakan tersebut tidak akan efektif dan efisien. Disposisi atau sikap para pelaksana akan menimbulkan dukungan atau hambatan terhadap pelaksanaan kebijakan tergantuk dari kesesuaian kompetensi dan sikap dari pelaksanan. Karena itu, pemilihan dan penetapan personalia pelaksana kebijakan dipersyaratkan individu-individu yang memiliki kompetensi dan dedikasi yang tepat pada kebijakan yang telah ditetapkan (Warjio Afandi, 2015).

Lebih lanjut, (Arifin.T, 2018) menghimpun beberapa teori yang berkenaan dengan variabelvariabel yang mempengaruhi pelaksanaan kebijakan publik, diantaranya:

\section{a. Teori Merilee S. Grindle}

Pelaksanaan kebijakan publik dalam teori Merilee S. Grindle dipengaruhi oleh dua variabel besar, yakni: isi kebijakan (content of policy); dan lingkungan implementasi (context of implementation). Variabel tersebut mencakup: sejauhmana kepentingan kelompok sasaran tertuang dalam isi kebijakan; jenis manfaat yang diterima oleh kelompok sasaran; sejauhmana perubahan yang diinginkan dari sebuah kebijakan; apakah penempatan lokasi program sudah tepat; apakah sebuah kebijakan telah menyebutkan pelaksananya secara detail; dan apakah sebuah program didukung oleh sumberdaya yang memadai (Younistalb. Ed, 2015) 


\section{b. Teori Daniel A. Mazmanian dan Paul A. Sabatier}

Teori ini menyebut ada tiga kelompok variabel yang mempengaruhi keberhasilan pelaksanaan kebijakan publik, yaitu: karakteristik dari masalah (tractability of the problems), karakteristik kebijakan/ Undang- Undang (ability of statute to structure implementation), dan variabel lingkungan (nonstatutory variables affecting implementation) (Younistalb. Ed, 2015).

\section{c. Teori Donald S. Van Meter dan Carl E. Van Horn}

Teori Meter dan Horn menyatakan paling tidak dijumpai lima variabel yang mempengaruhi kinerja pelaksanaan kebijakan publik, yakni: standar dan sasaran kebijakan; sumberdaya; komunikasi antar organisasi dan penguatan aktivitas; karakteristik agen pelaksana; dan kondisi sosial, ekonomi dan politik. (Younistalb. Ed, 2015).

\section{Dimensi Pelaksanaan Kebijakan Publik}

Berdasarkan beberapa konsep dan sifat tindakan yang berkenaan dengan pelaksanaan Good Governance, menurut pemahaman penulis maka pelaksanaan kebijakan dapat diukur/ dievaluasi berdasarkan dimensi-dimensi: konsistensi, transparansi, akuntabilitas, keadilan, efektivitas, dan efisiensi (Rian. N.D, 2017).

\section{a. Konsistensi}

Pelaksanaan kebijakan berlangsung dengan baik apabila pelaksanaan kebijakan dilakukan secara konsisten dengan berpegang teguh pada prosedur dan norma yang berlaku.

\section{b. Transparansi}

Transparansi merupakan kebebasan akses atas informasi yang patut diketahui oleh publik dan/ atau pihak-pihak yang berkepentingan (Coryanata, 2007) dalam (Rian. N.D, 2017). Informasi yang berkenaan dengan pelaksanaan kebijakan publik perlu dilakukan bersifat terbuka, mudah, dan dapat diakses oleh semua pihak yang memerlukan, dan disediakan secara memadai, serta mudah dimengerti .

\section{c. Akuntabilitas}

Setiap aktivitas pelaksanaan kebijakan publik harus dapat dipertanggungjawabkan baik secara administratif maupun substantif, sesuai dengan ketentuan peraturan perundangundangan (Rian. N.D, 2017).

\section{d. Keadilan}

Keadilan secara umum dapat dipahami sebagai kebaikan, kebajikan, dan kebenaran, yang mengikat antara anggota masyarakat dalam mewujudkan keserasian antara penggunaan hak dan pelaksanaan kewajiban. Keadilan dalam kebijakan publik diwujudkan pada aktivitas pelayanan yang tidak diskriminatif. Pelaksanaan kebijakan publik tidak membedakan kualitas pelayanan pada kelompok sasaran berdasarkan pertimbangan suku, ras, agama, golongan, status sosial, dan lain-lain (Rian. N.D, 2017).

\section{e. Partisipatif}

Partisipasi masyarakat adalah keterlibatan dan peran serta masyarakat dalam pelaksanaan kebijakan. Partisipasi masyarakat disamping menopang percetapan pelaksanaan kebijakan, pada sisi lain akan berdampak pada proses evaluasi/ kontrol atas kinerja pemerintah dan dapat mampu menimalisir penyalahgunaan wewenang. Partisipasi masyarakat merupakan kunci sukses dari pelaksanaan kebijakan publik karena dalam partisipasi menyangkut aspek pengawasan dan aspirasi. Pengawasan yang dimaksud di sini termasuk pengawasan terhadap 
pihak eksekutif melalui pihak legislatif (Coryanata, 2007)dalam (Rian. N.D, 2017). Berdasarkan uraian tersebut, pelaksanaan kebijakan sebaiknya bersifat partisipatif, yaitu pelaksanaan kebijakan yang dapat mendorong peran serta masyarakat dengan memperhatikan aspirasi, kebutuhan, kepentingan, dan harapan masyarakat (Rian. N.D, 2017)

\section{f. Efektivitas}

Efektifitas berkenaan dengan pencapaian hasil yang telah ditetapkan, atau pencapaian tujuan dari dilaksanakannya tindakan, yang berhubungan dengan aspek rasionalitas teknis, dan selalu diukur dari unit produk atau layanan. Dalam pelaksanaan kebijakan publik, efektifitas diukur dari keberhasilan pencapaian tujuan dan sasaran yang telah ditetapkan pada kebijakan publik (Rian. N.D, 2017).

\section{g. Efisiensi}

Efisiensi berkenaan dengan jumlah penggunaan sumberdaya yang dibutuhkan untuk menghasilkan tingkat efektivitas tertentu. Efisiensi merupakan hubungan antara efektivitas dan penggunaan sumberdaya. Indikator ukuran yang dapat digunakan pada dimensi efisiensi adalah penggunaan sumberdaya yang dibutuhkan untuk mencapai tujuan yang ditetapkan, yang bisa diukur dengan tingkat pengunaan waktu, biaya, manusia, peralatan, dan sumberdaya lainnya (Rian. N.D, 2017).

\section{Metode Penelitian}

Penelitian ini merupakan penelitian kualitatif sesuai dengan obyek kajian artikel ini, maka jenis penelitian ini termasuk dalam kategori penelitian kepustakaan (library research). Menurut Kaelan, dalam penelitian kepustakaan kadang memiliki deskriptif dan juga memiliki ciri historis. Dikatakan historis karena banyak penelitian semacam ini memiliki dimensi sejarah, termasuk di dalamyna penelitian agama, misalnya tentang karya tokoh pemikir keagamaan masa lalu seperti imam alGhaza dan lain sebagainya. Penelitian karya-karya tokoh agama tersebut termasuk penelitian kepustakaan. Penelitian kepustakaan ini bisa meliputi kritik pemikiran, penelitian sejarah agama, dan dapat pula penelitian tentang karya tertentu atau naskah tertentu. Oleh karenanya penelitian kepustakaan akan menghadapi sumber data berupa buku-buku yang jumlahnya sangat banyak sehingga memerlukan motode yang memadai ( Mestika Zed, 2018).

Untuk itu dalam penelitian kepustakaan, mengumpulkan buku harus secara bertahap, sebab akan kesulitan apabila tidak demikian. Penelitian kualitatif disebut juga dengan penelitian naturalistic. Disebut kualitatif karena sifat data yang dikumpulkan bukan kuantitatif dan tidak menggunakan alat-alat pengukur statistik. Disebut naturalistic karena situasi lapangan penelitian bersifat wajar, tanpa dimanipulasi dan diatur oleh eksperimen dan tes. Liha (Nasution, 2015). Teknik pengumpulan data, dalam hal ini penulis melakukan identifikasi wacana dari buku-buku, makalah atau artikel, majalah, jurnal, web (internet), yang berhubungan dengan kebijakan publik.

\section{Pembahasan}

Hasil pembahasan menunjukkan bahwa implementasi kebijakan publik dipengaruhi oleh beberapa faktor, diantaranya: aspek kewenangan, sumberdaya, komunikasi, dan disposisi. Dimensidimensi yang dapat digunakan untuk mengevaluasi pelaksanaan kebijakan publik diantaranya: konsistensi, transparansi, akuntabilitas, keadilan, efektivitas, dan efisiensi. Sementara itu evaluasi pelaksanaan kebijakan perlu dilakukan secara komperhensif, yang meliputi: evaluasi ex-ante, on-going, dan ex-post atas pelaksanaan kebijakan publik. Dalam melakukan inovasi dan terobosan dalam pelayanan kepada publik, dapat dilakukan diskresi pelaksanaan kebijakan publik sepanjang tidak bertentangan dengan norma dan peraturan yang berlaku. 


\section{Kesimpulan}

1. Implementasi kebijakan merupakan hal yang sangat luas, meliputi bagaimana implementasi ditempatkan sebagai alat administasi hukum dan juga sekaligus dipandang sebagai fenomena kompleks sebuah proses atau hasil dari kebijakan. Situmorang juga menegaskan bahwa implementasi kebijakan adalah satu dari sekian banyak tahap kebijakan publik, sekaligus menjadi variabel terpenting yang memiliki pengaruh sangat besar terhadap keberhasilan kebijakan terkait penyelesaian isu-isu publik

2. Kebijakan publik adalah serangkaian keputusan yang menyangkut kepentingan publik, yang sadar, terarah, dan terukur yang dilakukan oleh pemerintah yang melibatkan para pihak yang berkepentingan dalam bidang-bidang tertentu yang mengarah pada tujuan tertentu. Sedangkan pelaksanaan kebijakan merupakan tahapan aktivitas/ kegiatan/ program dalam melaksanakan keputusan kebijakan yang dilakukan oleh individu/ pejabat, kelompok pemerintah, masyarakat, dan/ atau swasta dalam rangka pencapaian tujuan yang telah ditetapkan dalam keputusan kebijakan yang akan mempengaruhi hasil akhir suatu kebijakan.

3. Pelaksanaan kebijakan publik dipengaruhi oleh beberapa faktor, diantaranya: aspek kewenangan, sumberdaya, komunikasi, dan disposisi. Dimensi-dimensi yang dapat digunakan untuk mengevaluasi pelaksanaan kebijakan publik diantaranya: konsistensi, transparansi, akuntabilitas, keadilan, efektivitas, dan efisiensi. Sementara itu evaluasi pelaksanaan kebijakan perlu dilakukan secara komperhensif, yang meliputi: evaluasi ex- ante, on-going, dan ex-post. Dalam melakukan inovasi dan terobosan dalam peningkatan pelayanan kepada publik, dapat dilakukan diskresi pelaksanaan kebijakan publik sepanjang tidak bertentangan dengan norma dan peraturan yang berlaku.

\section{Daftar Pustaka}

Andayaningsih Hernaman.(2018). Evaluation of In Vitro Digestibility of Dried Matter and Organic Matter of Solid Waste of Bioethanol Fermentation from Cassava by Trichoderma Viride Andsaccharomyces Cerevisiae. Journal of Asian Scientific Research, Vol.5. no. 1. ISSN: 1513-1121. Diakses Pada Tanggal 3 Juli 2020 Pukul 15.45 WIB

Arifin.T. 2018. Kebijakan Publik dan Transparansi Penyelenggaraan Pemerintahan Daerah. PT.PUSTAKA INDONESIA PRESS. Kemayoran Jakarta Pusat

Christiyanto.S. 2016. Faktor-Faktor yang Mempengaruhi Kelancaran Implementasi Program Rencana Pembangunan Jangka Menengah Daerah Kabupaten Kutai Barat Tahun 2011-2015. eJournal Administrative Reform, Vol. 4. No.2. ISSN: 2901- 3010. Diakses Pada Tanggal 1 Juli 2020 Pukul 22.45 WIB

Egetan, M. (2016). Evaluasi Kebijakan Pemberian Bantuan Pengembangan Usaha Mina Perdesaan di Kabupaten Minahasa Selatan. Society: Jurnal Ilmu Sosial \& Pengelolaan Sumberdaya Pembangunan, Vol.2. no.2. ISSN: 182-1274. Diakses Pada Tanggal 3 Juli 2020 Pukul 20.45 WIB

Erwan Agus Puwanto. 2018. Konsep dan Aplikasi Implementasi Kebijakan Publik. I.s. Islamy, I. (2019). Prinsip-Prinsip Perumusan Kebijakan Negara. Jakarta: Bumi Aksara. Iskandar, J. 2017. Kapita Selekta teori Administrasi Negara. Bandung: Puspaga.

Mestika Zed, 2018. Metode Penelitian Kepustakaan. Yayasan Obor Indonesia. Jakarta 
334 AT-TAWASSUTH:Jurnal Ekonomi Islam, Volume VI No. II Juli-Desember 2021: 324 - 334

Mthethwa, R. M. (2018). Critical Dimensions for Policy Implementation. African Journal of Public Affairs, Vol.5. no.2. ISSN: 0136-1142. Diakses Pada Tanggal 3 Juli 2020 Pukul 13.30 WIB

Rian. N.D . 2017. Kebijakan Publik: Formulasi, Implementasi, dan Evaluasi. Jakarta: PT. Elex Media Komputindo

Samodra.W.Dk. 2017. Evaluasi Kebijakan Publik. Jakarta: Raja Grafindo Persada.

Situmorang Chazali. 2016. Kebijakan Publik (Teori, Analisis, Implementasi dan Evaluasi Kebijakan). Social Security Development Institute (SSDI). Yogyakarta dalam Pencapaian Target Pajak Bumi dan Bangunan Perdesaan dan Perkotaan. Jurnal Administrasi Publik, Vol.6 no. 2. ISSN: 1192- 1013. Diakses Pada Tanggal 1 Juli 2020 Pukul 22.45 WIB

Yamin M. N (2016). Implementasi Kebijakan Perizinan dan Pemberitahuan Kegiatan Masyarakat pada Kepolisian Resort Kota Kendari. Publica, vol. 1. no. 1,ISSN: 2101- 1014. Diakses Pada Tanggal 1 Juli 2020 Pukul 22.45 WIB

Younistalb. Ed, 2015, Implementation of Public Policy, Sydney, Dartmouth. Zainal Abidin. 2017. Kebijakan Publik. (Edisi Revisi). Jakarta: Pancur Siwah. 